\title{
Zonisamidkezelés myoclonusdystoniában
}

\author{
Salamon András dr. ${ }^{1}$ - Zádori Dénes dr. ${ }^{1}$. Horváth Emese dr. ${ }^{2}$ \\ Vécsei László dr. ${ }^{1,3}$ - Klivényi Péter dr. ${ }^{1}$ \\ ${ }^{1}$ Szegedi Tudományegyetem, Általános Orvostudományi Kar, Szent-Györgyi Albert Klinikai Központ, \\ Neurológiai Klinika, Szeged \\ ${ }^{2}$ Szegedi Tudományegyetem, Általános Orvostudományi Kar, Szent-Györgyi Albert Klinikai Központ, \\ Orvosi Genetikai Intézet, Szeged \\ ${ }^{3}$ MTA-SZTE Idegtudományi Kutatócsoport, Szeged
}

\begin{abstract}
A myoclonusdystonia (DYT11) egy olyan ritka, autoszomális domináns módon öröklődő mozgászavar, melyet klinikailag myoclonus és/vagy dystonia jellemez. Hátterében leggyakrabban az e-szarkoglikán-gén (SGCE) mutációi állnak. A betegség oki terápiája jelenleg nem ismert. Tüneti kezelésként a zonisamidra, az inzulinterápiára, a karbamazepinre, valamint a zolpidemre vonatkozó adatok állnak rendelkezésre. Amennyiben a tünettan gyógyszeresen nem uralható, kétoldali globus pallidus internus mélyagyi stimulációs kezeléstôl várható javulás. A jelen közlemény célja Magyarországon elsőként a zonisamidkezelés hatékonyságának bemutatása egy genetikailag igazolt myoclonusdystoniás betegnél. 25 éves nőbetegünknek már gyermekkorában jelentkeztek az elsősorban a jobb felső végtagjára lokalizálódó, villanásszerű rángásai. E mellé elsősorban íráskor és járáskor jelentkező izomgörcsök társultak. Alkohol fogyasztása a tüneteket mérsékelte. Koponya-MRI-vizsgálat a panaszait magyarázó eltérést nem mutatott. Neurofiziológiai vizsgálatok subcorticalis myoclonust valószínúsítettek. A részletes fenotipizálást követően myoclonusdystonia iránydiagnózissal genetikai vizsgálat történt, amely a $S G C E$-gén 6. exonjának 709. pozíciójában egy heterozigóta formában jelen lévő citozin-timin cserét igazolt, amely korai stopkodon kialakulását okozta (c.709C>T, p.Arg237*). A kockázat-haszon arány mérlegelését követően zonisamidkezelés beállítása mellett döntöttünk, melyet 6 hét alatt fokozatosan emeltünk $300 \mathrm{mg} /$ die dózisig. A myoclonus- és dystoniaspecifikus tesztek jelentős javulást mutattak a kezelés előtti állapothoz képest. Az ismertetett eset célja, hogy felhívja a figyelmet a betegségre, annak potenciálisan életminőséget javító kezelésére, valamint a társszakmák (neurológus, pszichiáter, genetikus) közötti együttmúködés fontosságára.
\end{abstract}

Orv Hetil. 2019; 160(34): 1353-1357.

Kulcsszavak: myoclonusdystonia, alkoholreszponzív dystonia, zonisamid, SGCE

\section{Zonisamide treatment in myoclonus-dystonia}

Myoclonus-dystonia (DYT11) is a rare, autosomal dominant hereditary disorder clinically characterized by myoclonus and/or dystonia. The disease is most commonly caused by the mutations of the SGCE gene. Causative therapy is not available currently. Regarding symptomatic treatment, zonisamide, insulin therapy, carbamazepine and zolpidem may be utilized. If these drugs are not effective, bilateral globus pallidus internus deep brain stimulation may come into consideration. The aim of this study is to demonstrate the efficacy of zonisamide treatment in a Hungarian patient with genetically proven myoclonus-dystonia. Our 25-year-old female patient has had jerky, lightninglike movements since her childhood, mainly localized to her right upper limb. In addition, muscle cramps associated with writing and walking were also present. The symptoms were reduced by alcohol consumption. Brain MRI did not show any abnormality. Neurophysiological studies raised the possibility of subcortical myoclonus. After detailed phenotyping, genetic testing was performed, yielding the diagnosis of myoclonus-dystonia. A heterozygous mutation in the 6th exon of the SGCE gene at the position 709, resulting in an early stop codon (c.709C> T, p.Arg237*) was demonstrated. After considering the risk-benefit ratio, we decided to start zonisamide treatment. The dose was titrated gradually to $300 \mathrm{mg} / \mathrm{d}$ over 6 weeks. Myoclonus- and dystonia-specific tests demonstrated significant improvement compared to the pre-treatment status. The aim of this case report is to draw attention to this rare condition, its treatment and the importance of collaboration between medical subspecialties.

Keywords: myoclonus-dystonia, alcohol-responsive dystonia, zonisamide, SGCE

Salamon A, Zádori D, Horváth E, Vécsei L, Klivényi P. [Zonisamide treatment in myoclonus-dystonia]. Orv Hetil. 2019; 160(34): 1353-1357.

(Beérkezett: 2019. március 5.; elfogadva: 2019. március 23.) 


\section{Rövidítések}

ADCY5 = adenilát-cikláz-5; AKV = Addenbrooke-féle kognitív vizsgálat; $\mathrm{BDI}=($ Beck depression inventory) Beck-féle depresszió-kérdő́iv; BFM-D = (Burke-Fahn-Marsden dystonia rating scale) Burke-Fahn-Marsden-féle rokkantsági skála; BFM$\mathrm{M}=$ (Burke-Fahn-Marsden dystonia rating scale-movement) Burke-Fahn-Marsden-féle dystoniapontozó skála; CACNAlB = N-típusú feszültségfüggő kalcium $\left(\mathrm{Ca}^{++}\right)$-csatorna alfa-lb alegysége DAGC $=($ dystrophin-associated glycoprotein complex) disztrofinasszociált glikoproteinkomplex; DRD2 = dopaminreceptor D2; DYT11, $-15,-23,-26=$ myoclonusdystonia-11, -15, -23, -26; EEG = elektroencefalográfia; GABA = (gamma-aminobutyric acid) gamma-amino-vajsav; GPi-DBS = (globus pallidus interna deep brain stimulation) globus pallidus internus mélyagyi stimuláció; KCTDl7 = kálium $\left(\mathrm{K}^{+}\right)$-csatorna tetramerizációs domént tartalmazó fehérje-17; LGMD = (limb-girdle muscular dystrophy) végtagöv típusú izomdisztrófia; $\mathrm{MRI}=$ (magnetic resonance imaging) mágnesesrezonancia-képalkotás; NKX2-1 = NK2 homebox 1; RELN = reelin; $S G C E=$ (epsilon-sarcoglycan gene) $\varepsilon$-szarkoglikán-gén; SSEP $=($ somatosensory evoked potential $)$ szomatoszenzoros kiváltott válasz; UMRS = (unified myoclonus rating scale) egysége sített myoclonuspontozási skála

A myoclonusdystonia (DYTl1) egy olyan ritka, autoszomális domináns módon öröklődő mozgászavar, amelyet klinikailag myoclonus és dystonia együttes előfordulása jellemez [1-4]. Prevalenciája Európában 2 : 1000000 [2]. A betegség általában az 1-2. évtizedben, elsősorban a felső testfélre lokalizálódó myoclonusokkal, valamint az esetek egy részében ehhez társuló dystoniával (a leggyakrabban cervicalis dystonia, vagy írásgörcs) kezdődik [2]. A páciensek kb. 15-30\%-ánál izoláltan csak dystonia van jelen [1]. Alkohol fogyasztása jelentősen javítja a tüneteket, emiatt fennáll az alkoholdependencia veszélye [5]. A szorongásos kórképek, valamint az obszesszívkompulzív zavarok előfordulása gyakoribb ebben a populációban [5]. A betegség hátterében a leggyakrabban a 7. kromoszóma hosszú karján lévő, 13 exonból álló ع-szarkoglikán-gén (SGCE) mutációi állnak, leírásra kerültek azonban már egyéb eltérések is $[1,2,6-10]$
(1. táblázat). A betegség patomechanizmusa részleteiben nem teljesen tisztázott. Az $\varepsilon$-szarkoglikán egy transzmembrán fehérje, amely a disztrofinasszociált glikoproteinkomplex (DAGC) része [2]. Ennek fó feladata az extracelluláris mátrix, valamint a cytoskeleton közötti kapcsolat megteremtése [2]. A komplex további összetevőit $\left(\alpha-, \beta-, \gamma_{-}^{-}, \delta\right.$-szarkoglikán) összefüggésbe hozták végtagöv típusú (limb-girdle) izomdisztrófiákkal (LGMD) $[2,11]$. A kórismét a módosított diagnosztikus kritériumok alapján állíthatjuk fel (2. táblázat) [1].

2. táblázat |A myoclonusdystonia-szindróma diagnosztikus kritériumai [1]

\section{Major kritérium}

Izolált myoclonus, vagy dystonia jelenlétekor a myoclonus dominálja a klinikai képet

A motoros tünetek elsősorban a felső testfélre lokalizálódnak

A törzsi dystonia hiánya

Pozitív családi anamnézis

18 éves kor előtti betegségkezdet

\section{Minor kritérium}

Obszesszív-kompulzív zavar, szorongásos kórképek vagy alkoholdependencia jelenléte

Az alsó végtagi dystonia spontán remissziója a gyermekkor vagy a fiatal felnőtt kor folyamán

Alkoholreszponzivitás

\section{Kizáró kritériumok}

Egyéb neurológiai tünet a myoclonuson és/vagy a dystonián túl

Kóros koponya-MRI

A diagnózist nem támogató neurofiziológiai vizsgálati eredmények

Diagnózis

Definitín diagnózis: 5 major kritérium jelenléte és a kizáró kritériumok hiánya esetén; 4 major és 2 minor kritérium jelenléte és a kizáró kritériumok hiánya esetén.

Valószínü diagnózis: 4 major kritérium jelenléte és a kizáró kritériumok hiánya esetén; 3 major és 2 minor kritérium jelenléte és a kizáró kritériumok hiánya esetén.

MRI = mágnesesrezonancia-képalkotás

1. táblázat |A myoclonusdystonia-szindróma lehetséges genetikai háttere

\begin{tabular}{|c|c|c|c|}
\hline Kromoszomális lokalizáció & Fenotípus (MIM) & Öröklődés & Gén $(\mathrm{MIM})$ \\
\hline $7 \mathrm{q} 21.3$ & Dystonia-11, myoclonusdystonia (159900) & $\mathrm{AD}$ & SGCE (604149) \\
\hline $3 \mathrm{q} 21.1$ & Familiaris dyskinesia facialis myokymiával (606703) & $\mathrm{AD}$ & ADCY5 (600293) \\
\hline $22 \mathrm{q} 12.3$ & Dystonia-26, myoclonusdystonia (616398) & $\mathrm{AD}$ & KCTD17 (616386) \\
\hline $9 \mathrm{q} 34.3$ & Dystonia-23 $(614860)$ & $\mathrm{AD}$ & CACNA1B (601012) \\
\hline $7 \mathrm{q} 22.1$ & Familiaris temporalis lebenyi epilepszia (616436) & $\mathrm{AD}$ & RELN (600514) \\
\hline $9 \mathrm{q} 34.11$ és $11 \mathrm{q} 23.2$ & Dystonia-1 (128100) és dopaminreceptor D2 (?) & $\mathrm{AD} ; ?$ & DYT1 (605204) és DRD2 (126450) \\
\hline $18 \mathrm{pll}$ & Dystonia-15, myoclonusdystonia $(607488)$ & $\mathrm{AD}$ & $?$ \\
\hline $14 \mathrm{q} 13.3$ & Benignus herediter chorea l-es típus (118700) & $\mathrm{AD}$ & NKX2-1 (600635) \\
\hline
\end{tabular}

MIM = Mendelian Inheritance in Man azonosító

$\mathrm{AD}=$ autoszomális domináns; ADCY5 = adenilát-cikláz-5; CACNAlB = N-típusú feszültségfüggő kalcium $\left(\mathrm{Ca}^{++}\right)$-csatorna alfa-1b alegysége; DRD2 = dopaminreceptor D2; DYT1 = myoclonusdystonia; KCTD17 = kálium $\left(\mathrm{K}^{+}\right)$-csatorna tetramerizációs domént tartalmazó fehérje-17; NKX2-1 = NK2 homebox 1; RELN = reelin; SGCE = $\varepsilon$-szarkoglikán-gén 
A kivizsgálás részét képezi a koponya-MRI-vizsgálat, amellyel a panaszok hátterében álló esetleges strukturális abnormalitások kizárhatók, valamint a myoclonus subcorticalis eredetének tisztázása érdekében neurofiziológiai vizsgálatok elvégzése is elengedhetetlen [1, 12]. A betegség oki terápiája nem ismert, a kezelésre vonatkozó egyértelmú irányelv nem áll rendelkezésre.

\section{Esetismertetés}

A 25 éves nőbeteget időszakosan jelentkező, villanásszerû rángások, valamint az elsősorban íráskor és járáskor jelentkező izomgörcsök miatt észleltük. Túlmozgásait a stressz fokozta, alkohol fogyasztása csökkentette. A család elmondása szerint először 6 éves korában vették észre a jobb felső végtagra lokalizálódó, főként íráskor jelentkező rángásokat. Ezt követően egy rövid időre csökkentek a panaszok a környezeti stressz csökkentésével, azonban 14 évesen ismét jelentkeztek, így részletes neurológiai és pszichiátriai kivizsgálás történt. A fenti mozgászavart pszichogénnek véleményezték, és többféle szedatívumot, antidepresszánst indítottak (alprazolám, klonazepám, valproát, klomipramin, szertralin), melyekre érdemi javulás nem következett be. Családi anamnéziséből megemlítendő, hogy a beteg anyai dédnagyanyja epilepsziabetegségben szenvedett (1. ábra).

A beteg neurológiai vizsgálatakor elsősorban a felső testfélre lokalizálódó, de az alsó végtagokon is időszakosan jelentkező myoclonusokat, valamint jobbkéz-írásgörcsöt és járáskor jelentkező alsó végtagi, distalis túlsúlyú dystoniát lehetett megfigyelni. Az elvégzett laboratóriumi vizsgálatok (ionok, gyulladásos paraméterek, vese-, májfunkció, kvalitatív vérkép, véralvadási paraméterek) eltérést nem mutattak. Altatásos koponyaMRI-vizsgálat történt, amely strukturális abnormalitást nem írt le. Az EEG-vizsgálat a myoclonus epilepsziabetegséghez való kapcsolódására utaló epilepsziás múködészavart nem igazolt, továbbá a SSEP-vizsgálat corticalis myoclonusra jellegzetes corticalis óriáspotenciált nem

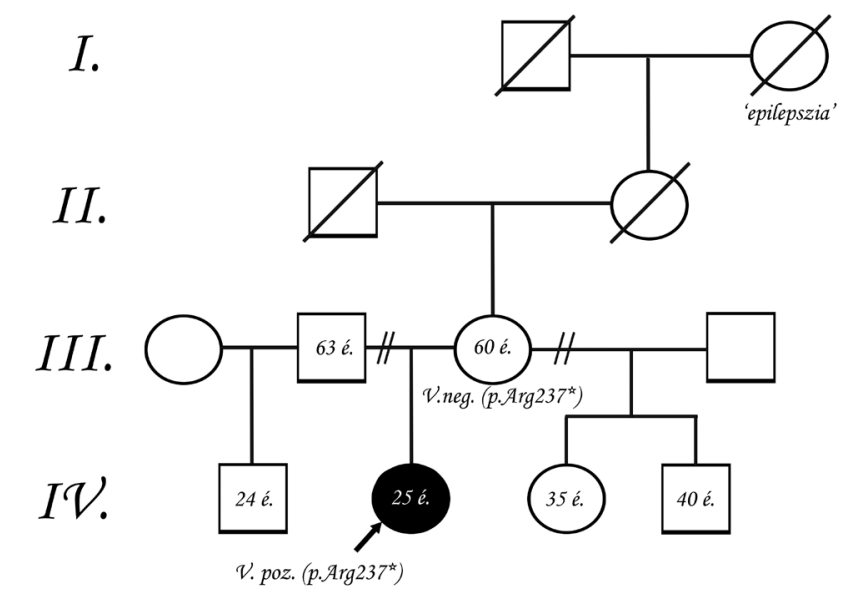

1. ábra

Családfa (p. - proband; V. [poz./neg.] - genetikai vizsgálaton átesett [pozitív/negatív]; kettős vonal - válás; római szám - generáció) mutatott, habár a vizsgálat szenzitivitása korlátozott értékű [28]. Így a tünettannal összhangban leginkább subcorticalis myoclonus jelenléte volt valószínúsíthető. Tekintettel arra, hogy a beteg klinikuma, valamint az elvégzett vizsgálatok eredményei (DYTl genetikai vizsgálat során CAG deletio nem igazolódott) a módosított myoclonusdystonia kritériumrendszerének megfeleltek, genetikai vizsgálat történt DYT11 iránydiagnózissal. Ez a $S G C E$-gén 6. exonjának 709. pozíciójában egy már korábban leírt heterozigóta formában jelen lévő citozintimin cserét igazolt, amely korai stopkodon kialakulását okozta (c.709C>T, p.Arg237*) [20, 21]. Az irodalomban két, ezzel azonos mutációval járó esetet találtunk, ahol a tünetek korábban kezdődtek, de fenotípusuk páciensünkével lényegében megegyező volt [20]. Szegregációanalízis során a beteg édesanyjánál volt lehetőségünk genetikai vizsgálatot végezni, nála patogén eltérés nem igazolódott. A beteg édesapjával a család nem tartotta a kapcsolatot, így az ő esetében genetikai vizsgálat nem volt kivitelezhető.

Valamennyi, a betegnél korábban pszichogénnek véleményezett mozgászavar indikációjával indított szedatív, valamint antidepresszáns-kezelés (alprazolám, klonazepám, valproát, klomipramin, szertralin) a mozgászavarra semmilyen hatással nem volt, azonban kifejezett fáradékonyságot és az iskolai teljesítőképesség csökkenését hozták magukkal. A myoclonusdystoniára vonatkozóan gyógyszeres terápiaként egyedül a zonisamidra vonatkozóan történt randomizált, kettős vak-, placebokontrollált vizsgálat (I. szintû evidencia) [13]. A beteggel egyeztetett módon, az indikáción túli gyógyszeres kezelésre vonatkozó engedély beadását és elfogadását követően, zonisamidterápia beállítása mellett döntöttünk, amelyet 6 hét alatt, fokozatosan titráltunk fel (1. hét: este $50 \mathrm{mg} ; 2$. hét: este $100 \mathrm{mg} ; 3$. hét: este 150 mg; 4. hét: este $200 \mathrm{mg} ; 5$. hét: este $250 \mathrm{mg}$; 6 . hét (céldózis): este $300 \mathrm{mg}$ ) [1, 12, 13]. A betegnek érdemi mellékhatása nem jelentkezett, enyhe fokú bizonytalanságérzésről számolt be hirtelen felállást követően. Az állapotváltozás objektivizálása céljából részletes myoclonus- (UMRS - egységesített myoclonuspontozó skála) és dystoniaspecifikus (BFM-M - Burke-Fahn-Marsdenféle dystoniapontozó skála; BFM-D - Burke-FahnMarsden-féle rokkantsági skála) tesztek kerültek kitöltésre a kezelést megelőzően, valamint a céldózis elérésekor, melyek egyértelmú javulást mutattak (3. táblázat). Emellett megtörtént a kezelést megelőzően a páciens kognitív és hangulati állapotfelmérése (AKV - Addenbrooke-féle kognitív vizsgálat; BDI - Beck-féle depreszszió-kérdőív). Ezen tesztek eltérést nem mutattak.

Az esetismertetés megírása a vizsgált személyek tájékozott írásos beleegyezését követően történt (az intézményi etikai engedély száma: 44/2016.). A betegvizsgálat során alkalmazott összes eljárás összhangban volt az intézményi etikai bizottság, valamint a helsinki deklaráció és annak későbbi módosításainak etikai standardjaival. 
3. táblázat | Klinikai állapotfelmérő skálák zonisamidkezelés előtt és után

\begin{tabular}{lcc}
\hline Teszt & Kezelés elött & $\begin{array}{c}\text { Kezelés után } \\
\text { (300 mg/die zonisamide) }\end{array}$ \\
\hline Burke-Fahn-Marsden-féle dystoniapontozó skála (BFM - movement) & $12 / 120$ pont & $6 / 120$ pont \\
\hline Burke-Fahn-Marsden-féle rokkantságpontozó skála (BFM - disability) & $3 / 30$ pont & $1 / 30$ pont \\
\hline Egységes myoclonuspontozó skála (UMRS) & $77 / 365$ pont & $41 / 365$ pont \\
\hline UMRS I. rész - Betegkérdőív (a páciens állapotértékelése)* & $4 / 44$ pont $(1 / 4$ pont) & $1 / 44$ pont $(0 / 4$ pont $)$ \\
\hline UMRS II. rész - Myoclonus nyugalomban & $14 / 108$ pont & $2 / 108$ pont \\
\hline UMRS III. rész - Stimulus szenzitivitás & $14 / 17$ pont & $10 / 17$ pont \\
\hline UMRS IV. rész - Feladatvégzés közbeni myoclonus & $31 / 160$ pont & $26 / 160$ pont \\
\hline UMRS V. rész - Funkcionális tesztek & $11 / 28$ pont & $2 / 28$ pont \\
\hline UMRS VI. rész - Globális rokkantsági pontszám (GDS) & $2 / 4$ pont & $0 / 4$ pont \\
\hline
\end{tabular}

*Tájékozódó jellegű vizsgálat

\section{Megbeszélés}

A myoclonusdystonia egy olyan ritka, herediter mozgászavar, melynek kuratív kezelése jelenleg nem ismert. A betegség kezelésére vonatkozóan egyedül a zonisamidra vonatkozóan történt kettős vak-, placebokontrollált klinikai vizsgálat [13]. A kétoldali pallidalis célpontú mélyagyi stimulációs (GPi-DBS) kezelés hatékonyságát illetően esetsorozat-vizsgálat áll rendelkezésre [17].

Kis tanulmányokból, valamint 1-1 esetközlésből származó adatok alapján feltételezik az inzulinterápia, a karbamazepin, a zolpidem, egyes benzodiazepinek, valamint az antikolinerg gyógyszerek szimptómás kezelésben betöltött hatékonyságát [1, 14-16].

A zonisamid egy olyan, a szulfonamidok csoportjába tartozó antiepileptikum, amely számos mechanizmuson keresztül fejti ki hatását: 1) a feszültségfüggő nátrium- és a T-típusú kalcium $\left(\mathrm{Ca}^{++}\right)$-csatornák blokkolása, 2) gyenge karboanhidrázgátló hatás, 3) GABAerg, glutamáterg, kolinerg, dopaminerg neurotranszmissziós folyamatok befolyásolása [22]. Epilepsziában, kiegészítő kezelésként, Parkinson-kórban, migrénben, másodlagos paroxysmalis dyskinesiákban, valamint egyes neuropszichiátriai kórképekben már rendelkezésre állnak a hatékonyságára vonatkozó adatok [22-27].

Betegünknél a pontos genetikai diagnózis felállítása után, hosszas kockázat-haszon mérlegelést követően döntöttünk a zonisamidkezelés beállítása mellett a mélyagyi stimulációs kezeléssel szemben, melyre a beteg állapota jelentősen javult. Összefoglalva, az általunk közölt eset az első magyar, zonisamiddal kezelt, genetikailag igazolt myoclonusdystoniás beteg. A közlemény célja, hogy felhívja a figyelmet a betegségre, valamint annak potenciálisan életminőséget javító kezelésére. A betegség kivizsgálása, kezelése és követése multidiszciplináris együttmúködést igényel (neurológus, pszichiáter, genetikus).
Anyagi támogatás: A jelen tanulmány összeállítását a Nemzeti Agykutatási program (No. 2017 1.2.1-NKP2017-00002_VI/4) támogatta. Zádori Dénes a Magyar Tudományos Akadémia Bolyai János Kutatási Ösztöndíjának támogatásában részesült.

Szerzői munkamegosztás: S. A.: A beteg kezelése, a kézirat megírása. H. E.: Genetikai diagnosztika, genetikai tanácsadás. V. L.: Szervezeti, strukturális háttér biztosítása. Z. D.: Szupervízió, a beteg gondozása. K. P.: Diagnosztika, a beteg gondozása, szupervízió. A cikk végleges változatát valamennyi szerző elolvasta és jóváhagyta.

Érdekeltségek: A szerzőknek nincsenek érdekeltségeik.

\section{Irodalom}

[1] Roze E, Lang AE, Vidailhet M. Myoclonus-dystonia: classification, phenomenology, pathogenesis, and treatment. Curr Opin Neurol. 2018; 31: 484-490.

[2] Rachad L, El Kadmiri N, Slassi I, et al. Genetic aspects of myoclonus-dystonia syndrome (MDS). Mol Neurobiol. 2017; 54: 939-942.

[3] Carbon M, Raymond D, Ozelius L, et al. Metabolic changes in DYT11 myoclonus-dystonia. Neurology 2013; 80: 385-391.

[4] Jie F. Research advances on the treatment of myoclonus-dystonia syndrome. J Neurol Neurophysiol. 2014; 5: 228.

[5] Peall KJ, Dijk JM, Saunders-Pullman R, et al. Psychiatric disorders, myoclonus dystonia and SGCE: an international study. Ann Clin Transl Neurol. 2016; 3: 4-11.

[6] Douglas AG, Andreoletti G, Talbot K, et al. ADCY5-related dyskinesia presenting as familial myoclonus-dystonia. Neurogenetics 2017; 18: 111-117.

[7] Mencacci NE, Rubio-Agusti I, Zdebik A, et al. A missense mutation in KCTD17 causes autosomal dominant myoclonus-dystonia. Am J Hum Genet. 2015; 96: 938-947.

[8] Groen JL, Andrade A, Ritz K, et al. CACNAlB mutation is linked to unique myoclonus-dystonia syndrome. Hum Mol Genet. $2015 ; 24$ : 987-993.

[9] Groen JL, Ritz K, Jalalzadeh H, et al. RELN rare variants in myoclonus-dystonia. Mov Disord. 2015; 30: 415-419. 
[10] Balicza P, Grosz Z, Molnár V, et al. NKX2-1 new mutation associated with myoclonus, dystonia, and pituitary involvement. Front Genet. 2018; 9: 335.

[11] Ritz K, van Schaik BD, Jakobs ME, et al. SGCE isoform characterization and expression in human brain: implications for myoclonus-dystonia pathogenesis? Eur J Hum Genet. 2011; 19: $438-444$.

[12] Levy A, Chen R. Myoclonus: pathophysiology and treatment options. Curr Treat Options Neurol. 2016; 18: 21.

[13] Hainque E, Vidailhet $M$, Cozic N, et al. A randomized, controlled, double-blind, crossover trial of zonisamide in myoclonus-dystonia. Neurology 2016; 86: 1729-1735.

[14] Gazzina S, Alberici A, Padovani A, et al. Myoclonic dystonia (DYTl1) responsive to insulin therapy: a case report. Neurology 2017; 89: 517-518.

[15] Sanjari Moghaddam H, Tafakhori A, Darvish H, et al. Treatment of myoclonus-dystonia with carbamazepine. Parkinsonism Relat Disord. 2018; 53: 116-117.

[16] Park IS, Kim JS, An JY, et al. Excellent response to oral zolpidem in a sporadic case of the myoclonus dystonia syndrome. Mov Disord. 2009; 24: 2172-2173.

[17] Rocha H, Linhares P, Chamadoira C, et al. Early deep brain stimulation in patients with myoclonus-dystonia syndrome. J Clin Neurosci. 2016; 27: 17-21.

[18] Sarva H, Miravite J, Swan MC, et al. A case of myoclonus-dystonia responding to low-frequency pallidal stimulation. Tremor Other Hyperkinet Mov. 2017; 7: 460.

[19] Ramdhani RA, Frucht SJ, Behnegar A, et al. Improvement of isolated myoclonus phenotype in myoclonus dystonia after pallidal deep brain stimulation. Tremor Other Hyperkinet Mov. 2016; 6: 369
[20] Grünewald A, Djarmati A, Lohmann-Hedrich K, et al. Myo clonus-dystonia: significance of large SGCE deletions. Hum Mutat. 2008 ; 29 : 331-332.

[21] Xiong HY, Alipanahi B, Lee LJ, et al. RNA splicing. The human splicing code reveals new insights into the genetic determinants of disease. Science 2015; 347: 1254806 .

[22] Janszky J. Role of zonisamid in treating epilepsy, Parkinson disorders and other neurological diseases. [A zonisamide szerepe az epilepszia, a Parkinson-kór és más neurológiai betegségek kezelésében.] Ideggyógy Szle. 2009; 62: 383-389. [Hungarian]

[23] Miwa H. Zonisamide for the treatment of Parkinson's disease. Expert Rev Neurother. 2007; 7: 1077-1083.

[24] Farooq MU, Moore PW, Bhatt A, et al. Therapeutic role of zonisamide in neuropsychiatric disorders. Mini Rev Med Chem. 2008; 8: 968-975.

[25] Chung JY, Kim MW, Kim M. Efficacy of zonisamide in migraineurs with nonresponse to topiramate. Biomed Res Int. 2014; 2014: 891348.

[26] Egel RT, Hoganson GE, Katerji MA, et al. Zonisamide ameliorates symptoms of secondary paroxysmal dystonia. Pediatr Neurol. 2010; 43: 205-208

[27] Romigi A, Femia EA, Fattore C, et al. Zonisamide in the management of epilepsy in the elderly. Clin Interv Aging 2015; 10 : 931-937.

[28] Cassim F, Houdayer E. Neurophysiology of myoclonus. Neurophysiol Clin. 2006; 36: 281-291.

(Klivényi Péter dr., Szeged, Semmelweis u. 6., 6725 e-mail: klivenyi.peter@med.u-szeged.hu)

\title{
MEGHÍVó
}

\author{
A Magyar Táplálkozástudományi Társaság szeretettel várja \\ az ez évi Vándorgyülésére a táplálkozástudomány iránt érdeklődő orvosokat.
}

Helyszín: Székesfehérvár, Hotel Novotel

Időpont: 2019. október 3-5.

Részletek: www.mttt.hu

A cikk a Creative Commons Attribution 4.0 International License (https://creativecommons.org/licenses/by/4.0/) feltételei szerint publikált Open Access közlemény, melynek szellemében a cikk bármilyen médiumban szabadon felhasználható, megosztható és újraközölhető, feltéve, hogy az eredeti szerző és a közlés helye, illetve a CC License linkje és az esetlegesen végrehajtott módosítások feltüntetésre kerülnek. (SID_1) 